\title{
National museums, national myths: constructing socialist Yugoslavism for Croatia and Croats
}

\author{
Joel Palhegyi* \\ Department of History, University of California San Diego, La Jolla, CA, USA
}

(Received 15 February 2016; accepted 15 August 2016)

\begin{abstract}
This article concerns two national museums in Croatia during the socialist period, the Museum of the Revolution of the Peoples of Croatia and the Historical Museum of Croatia. Both state-developed institutions were intimately tied to the process of nationalization as they helped articulate the place of the Croatian nation within the ideology of supranational Yugoslavism founded on the ideas of socialist patriotism, brotherhood and unity, self-management, national assertion, and South Slavic culture and community. This paper therefore traces the development and collapse of Yugoslavism in Croatia's national narrative by analyzing how these museums adapted the mythology of socialist Yugoslavism for a particularly Croatian context. Specifically, this paper investigates the ways in which these museums operated in an often ambiguous national-supranational discourse in order to reinforce the historical precedents of Croatia as part of the Socialist Federal Republic of Yugoslavia. I argue that these museums were envisioned by party elites and museum curators alike as essential to the project of building socialist Yugoslavism by adapting and altering Croatia's previous national pantheon of heroes, places, objects, and events to fit into a larger and distinctly supranational Yugoslav framework.
\end{abstract}

Keywords: Croatia; Yugoslavia; museums; Communism; nationalism

\section{Introduction}

During the socialist period, Yugoslavia's official state culture - the centrally planned and state-sanctioned set of values and beliefs propagated by the League of Communists was built upon a handful of universal principles that bound the different South Slavic nations under the banner of supranational Yugoslavism. Stock phrases such as "Brotherhood and Unity" and foundational events such as the People's Liberation Struggle during World War II served to circumvent the national tensions among the different peoples in Yugoslavia. This project was particularly pronounced in Croatia, home to some of the most anti-Yugoslav politics of the interwar period and the site of horrendous war crimes against ethnic Serbs perpetrated by the fascist Ustaša state during World War II. ${ }^{1}$

In this paper, I analyze two national museums in Zagreb that were particularly suited to promote this official culture, the Historical Museum of Croatia (renamed the Croatian Historical Museum in 1991) and the Museum of the Revolution of the Peoples of Croatia. Precisely because both museums stem from seemingly antagonistic ideological

*Email: jpalhegyi@ucsd.edu 
cores, national-liberal and supranational-socialist, they serve to illuminate the ways in which the Yugoslav state sought to reconcile the histories and the presence of multiple nations within a supranational, socialist framework. A key aspect of this process was the appropriation of Croatia's material culture to construct a series of myths that reinforced the legitimacy of socialist Yugoslavia. In particular, I focus on the most prominent of these myths for Yugoslav Croatia: the revolutionary state; popular socialist heroism; the historical precedents of Yugoslavism; and South Slavic and European Heritage.

My use of the terms "myth" and "mythology" is not meant to indicate falsehood or the fabrication of history. Rather, I use these terms to signify the projection of absolute truth in the process of telling history and celebrating cultural heritage, thereby establishing a nexus of common values, foundational events and heroes, and aspirations for the Yugoslav peoples. As Andrea Orzoff points out, myth and mythology "denote a worldview based on identifiably ideological narratives or images claiming to be universally valid, yet only accepted as true by certain audiences at certain times." More specifically, I follow Orzoff's approach by focusing on how myths are employed both culturally and politically in order to legitimate power, produce a set of universal morals and values, and define peoplehood (Orzoff 2009, 15).

With this in mind, I argue that as both products and producers of an official Croatian Yugoslav narrative, the exhibition activities of the Revolutionary Museum and the Historical Museum represent a state-led attempt to claim Croatian history and frame it within a socialist Yugoslav framework, itself a fluid category that allowed a fair amount of cultural and intellectual space for articulating the Croatian nation. In doing so, these museums often employed an ambiguous national discourse that referred to the Croatian nation with its singular people, and the territory of Croatia with its multiple peoples, interchangeably as part and parcel of the supranational Yugoslav idea. As such, these museums were important actors in the process of nationalizing the population of Croatia as both ethnic Croats and socialist Yugoslav citizens. Examining these two institutions side by side thus provides a unique look at the often-tenuous relationship between Croatian nationalism on the one hand, and supranational, socialist Yugoslavism on the other. Furthermore, since the breakup of Yugoslavia, the Croatian History Museum has continued to use some of the basic mythological tropes developed during the socialist period, albeit often with inverted meanings. Therefore, even if in popular discourse the legacy of Communist Yugoslavism is often downplayed and denied a place within Croatian national heritage, the legacy of socialist Yugoslavism is very much alive in contemporary conceptions of the Croat nation.

\section{National museums, nationalization, socialist Yugoslavism}

While often understood at the popular level as scientific and objective, national museums are better understood as inherently tied to the political, social, and cultural discourses and power structures of the society to which they belong. Not surprisingly, then, they often serve as powerful propaganda tools and centers for developing and distributing official mythologies about the state (Aronsson 2011; Knell 2011; Molyneaux 1994). Furthermore, national museums provide the "scenography and stage" for identity politics in which the individual can discover his or her place within the larger national body, in turn reifying the symbiotic nature of the individual and their national community (Knell 2011, 4). In the Communist context, this often played out in a more authoritarian manner with an emphasis on purely didactic items and displays and a lack of interpretive space. Yet, in principle, the process remains the same (Badica 2011; Pintar and Ignatović 2011; Sharenkova 2010). 
All of this was true for Croatian professional museology and museum practice during the socialist period. Certainly, museum professionals did not envision museums purely as propaganda tools but rather as sites for critical thought and visitor engagement where the masses would organically discover both their national and their socialist cultural values (Bauer 1953). At the same time, however, professionals understood museums as crucial sites for altering the consciousness of their visitors in order to instill Marxist historical truths about the course of human history toward socialism. Nowhere in these museums was there room for alternative voices or narratives outside of this dogmatic truth. This new goal of modern museology, to establish "a socialist environment of a new type" and produce "conscious citizens" (Vojnović 1953), paradoxically meant replicating the same bourgeois-national "Temples of Truth" model from which Yugoslav museologists so actively tried to distinguish themselves. ${ }^{2}$

To this end, I investigate how these two museums were involved in the process of nationalization in Yugoslav Croatia. As several scholars have pointed out, throughout much of Central and Eastern Europe, national fluidity and indifference was the rule, not the exception, and widespread national consciousness only developed well into the twentieth century after a series of state-led processes (Bryant 2007; Case 2009; Judson 2006; King 2002; Reill 2012; Zahra 2008). In Croatia, a distinctly Croatian national movement was already welldeveloped by the time the first Kingdom of Yugoslavia was established in 1918, ultimately undermining the development of an ethno-national Yugoslav identity (Banac 1984). As Aleksa Djilas argues, however, the ethno-national divisions and violence of the interwar period and subsequent civil war ultimately granted the Communist Partisans significant legitimacy among the masses as an "enlightened movement" whose supranational character appeared to transcend the chaos of the times (Djilas 1991, 183). Therefore, despite these deeply embedded national identities and the extraordinarily tumultuous nationalist politics of the previous decades, the wartime revolutionary experience revived popular support - or at least popular hope - for Yugoslavism as a supranational identity in parallel with ethnonationality. As such, I approach the process of nationalization in socialist Yugoslavia as an incomplete and ongoing project that fundamentally altered the nationalisms of the various peoples of Yugoslavia (Ramet 2002, xiii).

Tapping into this popular sentiment, the League of Communists under the leadership of Josip Tito sought to transform the "Yugoslav" idea into a more supranational and multinational form than the failed interwar Yugoslavism that was marked heavily by Serbian cultural and political dominance. The particular Croatian version of this emphasized first, the civic religion of Brotherhood and Unity based upon socialist patriotism and anti-fascism, social justice, and economic prosperity; second, the role of the Yugoslav state as a guarantor of Croat nationhood that protected statehood and recognized Croatia's national characteristics and particularities; and third, Croatia's common South Slavic culture and historical experience that bound it with Yugoslavia's other constituent nations and led them to a shared socialist revolution (Djilas 1991; Djokić 2003; Perica 2002).

Of course, this official form of Yugoslavism did not go unchallenged in Croatia. Throughout the socialist period, the Croatian national question percolated in Yugoslav society and politics, while broader political dissidence against the nature of the League of Communists, its monopoly on power, and the direction of the economy were more common than in other Eastern European Communist states. The structures of the 1953 constitution, for instance, had created "a disproportionally small Croatian faction" at the federal level and "permanent patterns" of predominately Serb and Montenegrin staffing of the federal offices that set the stage for future conflict over the representation of ethnic Croats in federal positions (Lampe 2000, 262). Likewise, the New Left movement of the 
mid-1960s, the student protests of 1968, and the Croatian Spring of 1970-1971 challenged outright much of the official culture and economic structures of socialist Yugoslavism (Fichter 2016; Lampe 2000). Finally, after a brief "golden age" between 1974 and 1981 when "the nationality question seemed ... to have been laid to rest," Yugoslav politics increasingly devolved to republic-based, ethno-specific quarrels over the direction of Yugoslav society that ultimately culminated in the rise of Slobodan Milošević and interethnic warfare (Ramet 2002, 6).

Yet, in spite of the resurgence of Croatian national grievances during the socialist period, as well as various pan-Yugoslav concerns over the federal structure of the state and its hybrid economy, the national narrative in each of these museums remained remarkably stable. The discursive content of these museums' exhibitions shows little evidence of these conflicts, suggesting that these official cultural institutions remained loyal to the concept of socialist Yugoslavia up until its dissolution.

\section{The Museum of the Revolution of the Croatian People}

Founded in 1945 as an official party organ, the Museum of the Revolution of the Peoples of Croatia was designed to exhibit a heroic narrative of the wartime Partisan resistance, the building of a socialist state and society, and Croatia's particular role in this. To do so, the Revolutionary Museum developed two main mythological concepts: first, the idea of popular socialist heroism that rooted the wartime revolution among the common people and appropriated the Croatian resistance as a Yugoslav phenomenon, ${ }^{3}$ and second, the myth of the Yugoslav state born from socialist revolution and therefore charged with forging a socially just, nationally emancipatory, and economically sound society. Specifically, this myth emphasized the postwar experience of "building socialism" as the ultimate embodiment of socialist revolution, linking the present state with the struggles and values of the wartime revolution.

\section{Popular socialist heroism}

Under its initial inception as the Museum of the People's Liberation Struggle, the Revolutionary Museum was dedicated primarily to memorializing the Yugoslav military and the wartime Partisan movement. As part of its reorientation in 1960, however, the museum expanded its content to emphasize the depth of Croatia's popular support for the revolution and its multinational character. Exhibitions were designed to emphasize the indigenous and organic development of the Croatian popular revolt and its fusion with the socialist Yugoslav movement. Likewise, individuals who were often obscure and not among the previous Croatian Yugoslav social elites were celebrated as exemplary socialist citizens, revolutionary fighters, and frequently martyrs. This hero-making, both individual and popular, amplified the allure and mystique of socialist Yugoslavism as a movement built by and for a heroic and united socialist people.

One example of the museum's original vision was the 1957 exhibition, "From Partisan Units to the Yugoslav Army," which reinforced the mythology of the Yugoslav army as the protector of its constituent nations and was geared toward children and schoolteachers. Tracing the development of paramilitaries within Croatia and their incorporation into the Yugoslav army, the exhibition depicted these Croatian paramilitaries as evidence of "the contribution of the people of Croatia in the general struggle of the peoples of Yugoslavia in national revolution," effectively attributing a socialist Yugoslav spirit to these nationally Croatian military units (Ščukanec 1957, 3). 
In similar fashion, the Revolutionary Museum hosted a 1973 exhibition titled, "Croatia, 1943." Focusing on a pivotal year in the course of Croatian liberation from Axis occupation, the exhibition presented a glorified narrative of the six-month offensive in Banija, Kurdun, and Lika against Italian occupiers, and the Croatian liberation council's founding and subsequent cooperation with the Partisan movement. In one sense, it was a distinctly national story of the Croatian people. Presenting a newspaper clipping with the headline, "Our Istria is free and reunited with the Croatian fatherland," alongside an image of Croat refugees and soldiers, the exhibition gave fair space for the particular Croatian nature of the event. At the same time, the Croatian uprising was positioned within the larger socialist Yugoslav cause against foreign occupiers and "internal traitors" that "secured the foundation of a new socialist Yugoslavia." Likewise, the exhibition emphasized the formation of the National Anti-Fascist Council of the People's Liberation of Croatia or ZAVNOH, the highest governing organ of the Croatian branch of the antifascist movement. While ZAVNOH was recognized as a product of Croatian popular action, it was mostly glorified for having established Yugoslav and Partisan relations within Croatia, and in particular for its contribution to the development of "brotherhood and unity between Croats and Serbs" (Babić 1973).

The Revolutionary Museum also often employed wartime art as a powerful representation of the popular struggle, as in the 1974 exhibition, "Art in the National Liberation Struggle of Croatia." The exhibition used an array of pieces ranging from the rough sketches of unknown soldiers to polished pieces of art as testaments to the suffering and strength of the resistance while "materializing the socialist ethics" of the Partisan movement (Mateljan 1974, 7). Accordingly, the artist,

fraught with the grave reality of a cultural worker and artist, was no less filled with the nobility of their artistic vision and the ideals of life ... and therefore could alone symbolize and signalize the universality of the advanced humane national spirit.

Similarly, the artist fought for the freedom of humankind and "negated the destruction and crimes of the fascist occupation, the Ustaše, and the Chetniks," and together with his or her people, the League of Communists, and Tito, sought "to ignite the torch of freedom, brotherhood, struggle, art and science, to preserve our culture and heritage from the destruction of fascist barbarism" (Božić 1974, 3).

Another exhibition framed wartime awards and medals as testaments to the popular and heroic nature of the resistance. As symbols of "permanent devotion and sacrifice," these awards served to illustrate not only the people's contribution to revolutionary state-building, but also the obligation of the state to acknowledge and respect those who participated (Kolar 1988). Likewise, an exhibition on wartime caricatures of Hitler and anti-fascist propaganda framed the materials as having a clear didactic value to represent the "programmatic work" of the resistance and reflect the "immediacy of action" of the Croatian people against the fascist occupiers (Ivanuša 1988).

Finally, the Revolutionary Museum held exhibitions on individual figures within the larger pantheon of socialist heroes, reinforcing and contributing to the socialist Yugoslav cult of personalities. For example, a 1986 exhibition on Andrija Maurović, a now famous Yugoslav-era author and comic book writer of Slovene-Montenegrin descent who spent most of his life in Croatia, included brutal and gritty sketches and comic strips depicting the sacrifice of the Partisans, as well as more refined drawings of heroic battle scenes. In addition, the exhibition focused on Maurović's role within the culture and art department of the ZAVNOH, where he produced materials for political agitation such as posters, fliers, slogans, caricatures, and drawings (Pavičić 1986). The rationale 
behind this exhibition, however, went beyond the value of Maurović's art, to focus on the figure of Maurović himself. As the exhibition brochure points out, although Maurović joined the Partisan forces relatively late (in the spring of 1944), "his honest ethics and socialist commitments were present much earlier," as evidenced by his continued interest in the October Revolution and the progressive ideas of Communism since high school. Because of this involvement, the brochure continues, Maurović was arrested and jailed from 1941 to 1943 and thus unable to join the cause, in turn preserving his socialist credentials (4).

A similarly emblematic example is an exhibition on Rade Končar from 1984, a celebrated Partisan figure and wartime secretary of the Communist Party of Croatia. Exhibiting newspapers describing him as "the most powerful personality" in the Croatian branch of the party and crediting him with founding almost every party organization in Croatia, the exhibition treated Končar as a poster boy for Partisan bravery (Kolar 1984, 1). He was an ethnic Serb born in a small village in western Croatia, but the brochure omits any discussion of ethnicity and highlights instead Končar's socialist accomplishments, beginning with his proletarian roots as a locksmith, his joining of the Youth Communist League of Yugoslavia (SKOJ) in 1932, his participation in a 1938 metalworkers strike, and his wartime administrative and military Partisan activities. The exhibition also describes Končar as honorable, politically active, and vital to the Communist movement within Croatia, to be emulated and remembered. Finally, in line with the exhibition's hagiographic nature, the brochure describes Končar's arrest and execution by the Italian secret police. Wounded and detained, Končar was "tortured in the cruelest fashion" and executed along with 25 fellow patriots (3).

\section{The revolutionary state}

A common phrase in socialist-era museology journals and museum brochures is "socialisitčka izgradnja," translated best as "the building of socialism." Taken literally, this refers to the process of building a socialist society and state. In the context of Yugoslavia, however, it was fundamentally linked to the People's Liberation Struggle and the revolutionary values it contained, such as socioeconomic justice and prosperity, national emancipation, and even gender equality. Accordingly, some the Revolutionary Museum's exhibitions sought to link contemporary events and phenomena in Croatia with the goals of the Worker's Movement and the People's Liberation Struggle.

One early example was the exhibition, "Cultural Work in the People's Liberation Struggle," which displayed the cultural accomplishments of the Partisans in Croatia, such as newspapers and periodicals, literature and folk art, literacy courses, and the opening of elementary schools. This "struggle against ignorance and cultural backwardness," rooted in popular activity and guided by the Croatian National Anti-Fascist Council, resulted in myriad small, local organizations coalescing "into full-fledged theatre companies." Furthermore, the exhibition projected these activities as an embodiment of the values of the working class, "the continuation of the pre-war efforts made by the working class, peasants and progressive intellectuals" that laid the foundation for cultural life in the new socialist state (Kulturni Rad, n.d., 2).

Another example, the 1970 exhibition, "A Quarter Century of Our Development," cast the current state as a continuation of the decades-long working-class movement. This exhibition used the revolutionary developments in social relations and the economy made so far under the Communist regime in part to justify the need for one-party rule and centralism in the 1940s and 1950s. As part of the revolution, political freedom was subordinated until the 
"indispensable material conditions for the further development of socialist relations" were created. The exhibition quickly moved on, however, to emphasize the progress in internal decentralization, democracy, and the improvement of daily life. In particular, the exhibition focused on postwar reconstruction of crucial economic infrastructure, such as factories, bridges, and rail lines, as well as specifically Croatian cultural monuments like the rebuilding of Split (Dešković and Ivanuša 1970).

In a similar vein, the exhibition presented the unique Marxist path of Yugoslavia and the resulting transition from a backward agricultural economy to a modern, industrial one. Keeping in mind that this was at the height of the economic boom of Yugoslavia, these images were likely to resonate with the average Croat citizen whose standard of living had steadily increased over the previous two decades (Patterson 2012). Reconstruction, decentralization, and economic progress were also linked to social justice. Alongside this narrative of economic reconstruction was one of popular participation, both socially and politically. For instance, the exhibition displayed an image of gleeful factory workers dancing around a Yugoslav flag with a newly constructed factory in the background. Likewise, two images were placed side by side in the exhibition brochure, one of electric workers at the ballot casting their votes for their elective workers council, and another of Tito and fellow party members at the Ninth Congress of the League of Communists of Yugoslavia (Dešković and Ivanuša 1970). While in reality the SKJ congresses were not democratic, the juxtaposition of these two images created a striking visualization of republican democracy and popular participation in the process of state-building.

Lastly, the Revolutionary Museum hosted a 1985 exhibition to promote the theme of gender equality and women's emancipation as a means to show its truly revolutionary character. Titled "The Women of Croatia in the Revolution," this exhibition considered the role of women and the need for gender equality in the long continuum of socialist revolution, displaying the long history of women's participation in the nineteenth- and twentieth-centuries' Workers' Movement, their role in the People's Liberation Struggle as both soldiers and nurses, and their modern place in Croatian society with "the same opportunities as men" as "scientists and highly educated experts." While women were credited with having achieved these successes through their own actions, the exhibition nonetheless points out that this was only made possible through the revolutionary state and "its vanguard - the Communist Party of Yugoslavia" (Purtić, n.d., 51). In this way, the exhibition coopted the broader goals of gender equality, emancipation, and social progress to present the socialist state as the ultimate culmination of women's rights and, therefore, truly revolutionary.

While it is easy to see the Revolutionary Museum as little more than a propaganda machine to justify party rule and subjugate Croat nationalism and national history in a more palatable and harmonious way, it was not so simple. By locating the Croat nation within the revolutionary story of the socialist Yugoslav state, the Revolutionary Museum was not actively denying Croat nationhood, its rights, or its history, but rather treating it as an integral part of the socialist Yugoslav story. The cultural achievements of the People's Liberation Struggle, the popular socialist heroism of the common people, and the culmination of these values in the current state all served to reinforce socialist Yugoslavism as the final embodiment of popular Croatian values. In this sense, then, these myths reinforced the idea that the Yugoslav state was in fact a protector and proponent of national assertion through its federalist system and thus grounded in the historical drive of the Croatian people toward national liberation and social justice. A similar process was taking place in the Historical Museum of Croatia, as well, only instead based on a much broader and diverse range of history. 


\section{The Historical Museum of Croatia}

Unlike the Revolutionary Museum, the Historical Museum of Croatia has a much longer history, dating to the nineteenth-century Croatian cultural revival. Founded in 1839 as the Croatian National Museum, the museum took on multiple functions including archaeology, history, and ethnography. These practices mostly continued during the interwar Kingdom of Yugoslavia, though in 1940 the Croatian National Museum was divided into more technically specific bodies, such as the Croatian National Archeological Museum and the Croatian National Zoological Museum, as well as the Croatian History Museum. The present form only emerged on the verge of World War II, which gave museum professionals little time to fully establish history as an independent branch of museology (Čaldarović 2008, 104).

During the socialist period, the museum was renamed the Historical Museum of Croatia and organized under the auspice of the Yugoslav Academy of Science and Art but retained its basic mission of "collecting and protecting various and compound cultural heritage ... to enable and to encourage complex historical studies" (Čaldarović 2008, 108-109). Yet as part of the new Communist state and under more or less direct state supervision, the myths of the Historical Museum had to be altered in accordance with the new socialist Yugoslav framework. Not surprisingly, therefore, the Historical Museum partook in a process similar to the Revolutionary Museum's socialist hero-making by means of appropriating older Croat national figures and stressing (or perhaps creating) their egalitarian proto-socialist values, their involvement with South Slavic movements such as Illyrianism or Slavonism, and their sympathies toward or involvement in early Communist movements. This reorientation served to position already known and celebrated, albeit not overtly nationalist, Croatian figures within a specifically Yugoslav framework, recognizing their specific national merits while re-narrating them as evidence of the historical precedents of socialist Yugoslavism. Additionally, due to the Historical Museum's far greater breadth of historical topics than the Revolutionary Museum, it could promote historical continuity between the more distant Croatian past and the Yugoslav present. Therefore, the Historical Museum was particularly suited to promote the cultural aspects of socialist Yugoslavism and its deep historical roots in the territory of Croatia. As a prime example of "in-between-ness," the culture of socialist Yugoslavism was grounded in both South Slav and Western European heritage. This "in-between-ness" served not only to promote socialist Yugoslavia's unique Cold War position as the leader of the Non-Alignment Movement but also to assert Croatia's cultural affinity for Central Europe while promoting common South Slavic heritage with its fellow Yugoslav nations.

\section{The historical precedents of Yugoslavism}

A striking example of the Historical Museum's appropriation of national heroes is a 1975 exhibition on Matij Ivanić, the leader of a sixteenth-century peasant revolt against Venetian rule. The exhibition brochure introduces Ivanić with a dramatic story of his rise as a social figure, beginning with the exploited condition of the Croatian peasants under foreign rule who, despite their efforts to negotiate more rights through the local assembly, were increasingly deprived of basic rights and harshly overworked. Born into a poor peasant family, Ivanić rose to lead the revolt and set up an egalitarian society the government referred to as "a unique oasis of democracy in feudal Europe" (Dančević 1975, 2). During this time, Ivanić successfully battled the mighty Venetian fleet while maintaining his commitment to his peasant followers. Eventually the revolt was defeated by Venetian forces and Ivanić fled to Vieste, trying unsuccessfully for the next five years to return and free his 
people (4). Clearly, the exhibition's narrative is saturated by a good deal of romanticism and mythologizing typical of national heroes. What is unique and revealing, however, is its emphasis on egalitarianism and activism that infuses Ivanić's heroism with a certain socialist spirit. For instance, the exhibition claims that Ivanić led a group of peasants directly into the Venetian Doge's palace to disrupt the speech of a senator while failing to explain how this was possible and what the repercussions were (Dančevic 1975, 3). Whether or not the event happened was of little importance: what mattered was Ivanić's social activism, his revolutionary spirit, and his commitment to the common man. In this sense, the Historical Museum depicted Ivanić as a sort of early-modern proto-socialist in order to exemplify the Croatian people's historical desire for social justice.

The Historical Museum continued this pattern in other exhibitions on nineteenth- and early twentieth-centuries' cultural and political figures who, in varying ways, contributed to the Yugoslav idea. While these figures generally were not egalitarian in their politics, their involvement in cultural-political movements espousing South Slav unity made them suitable candidates for renarrating their activities as part of the greater Croat historical drive toward Yugoslavism. Particularly suited for this was the nineteenth-century Illyrian movement, a cultural and later political movement for South Slav cultural unity, linguistic cohesion, national rights, and political autonomy. Though largely Croat-dominated in terms of its adherents and its cultural policies, the Illyrian Movement was employed by the Historical Museum to exemplify the historical impetus of Croat-Yugoslav unity. For example, the movement was framed in a 1967 exhibition as a bulwark against Germanization and Magyarization through its promotion of a common South Slav language and culture, as well as the adoption of the "common name" Illyrian in order to create an inclusive, South Slavic movement that did "not impose the name of a nation or region" (Schneider 1967, 2). Simultaneously, the brochure describes the movement's role in establishing a series of specifically Croatian cultural institutions within Zagreb, such as the National Theater and National Museum, in line with broader European national-bourgeois trends (4).

Some figures associated with the Illyrian movement were also given their own exhibitions. For instance, the Historical Museum in 1960 hosted an exhibition on the nineteenthcentury Croatian national cultural and political figure Ivan Kukuljević Sakcinski. Described as one of the most important and active Croatian revivalists, Sakcinski was lauded for his Illyrian activities and promotion of common South Slav culture, his work being dedicated to hoisting up Illyrianism, the founding of specifically Yugoslav cultural institutions, and the promotion of "the need for unity and celebration of our past" (Ivan Kukuljević Sakcinski 1960, 3). Similarly, the Historical Museum hosted a 1972 exhibition on Ljudevit Gaj, a founder and leader of the Illyrian movement. Displaying some of his written works on Illyrianism, the exhibition highlighted Gaj's main contribution to the movement: his articulation of a unique, South Slav literary language that "open[ed] the way for national life" (Ljudevit Gaj 1972, 2). Finally, in 1980, the Historical Museum hosted an exhibition on J.J. Strossmayer, one of the most revered Croatian national figures to this day. A founding figure of the Illyrian movement, devoted Catholic priest, and at one point leader of the People's Party, Strossmayer's story was quite suitable for expressing the historical drive of the Croat people toward Yugoslavism. The exhibition highlighted Strossmayer's contributions to both Croat and Yugoslav culture, such as founding the Yugoslav Academy of Sciences and Arts in Zagreb and his political project of "uniting the Southern Slavs that ran parallel to the struggle for the formation of the Croatian nation" (Borošak-Marijanović and Srzić 1980). Through these exhibitions, the Historical Museum appropriated the Illyrian movement in such a manner as to highlight its cultural and political contributions to the 
Yugoslav cause while sidestepping the historical reality that the movement was primarily Croat in character and often clashed with other South Slav, namely Serbian, interests.

While the Illyrian movement and its members dominated the Historical Museum's exhibiting of nineteenth-century Croat national figures, an exhibition of Frano Supilo is particularly illuminating of the rationale behind the museum's exhibition choices. Initially a member of the Croatian Party of Rights during the last decades of the nineteenth century and then a founding figure of the New Course and Croat-Serb Coalition in 1905, Supilo's political alignments were not as easily reconciled with the museum's promotion of Yugoslavism. It was precisely Supilo's opposition to the non-Yugoslav sentiments of each of these parties, however, that the exhibition highlighted, leading him to abandon each party in favor of a federal model of Yugoslavia wherein Croatia would constitute a federal state alongside Serbia, Bosnia and Herzegovina, Montenegro, and Slovenia. Therefore, despite the changing political currents surrounding him and the abandonment of Yugoslav ideas in each of these movements, "this sufferer of Croatian politics always aspired toward the same goal: unification, freedom, and equality of the Croatian people ... exhausting his last atom of strength in the struggle for his vision" (Stančić, n.d., 1). Supilo, according to the exhibition, was a Yugoslav visionary, "one of the most farsighted" and "honest fighters for the freedom and unification of the Croatian people and the creation of a Yugoslavia based on a community of equal peoples," despite his association with otherwise problematic political movements (7).

\section{South Slavic and European heritage}

Another central tenet of socialist Yugoslavism in Croatia was its cultural duality, claiming both Western European and South Slavic cultural heritage and emphasizing its cultural contributions to each of these distinct cultural poles. As Pintar and Ignatović argue in their study of the National Museum in Belgrade, the Yugoslav elites attempted to construct in national museums an "identity of the nation as a cultural crossroads, simultaneously insisting on the country's cultural authenticity and the notion of being a progressive member of European society with which it shares both historical traditions and value systems" (Pintar and Ignatović 2011, 795). Not surprisingly, then, the Historical Museum of Croatia similarly constructed this myth of cultural hybridity by locating Croatian and Yugoslav cultural achievements within Western and Central European cultural currents, while promoting South Slav particularisms of a more Eastern pole. This created a rather complex cultural nexus encapsulating European, Yugoslav, and Croat achievements that at once reflected commonality with the cultures on both sides of the Iron Curtain, while promoting the "authentic and mediatory" essence of the Yugoslav identity.

This was particularly true for exhibitions on musical composition, opera, and theater. The development of musical culture was both part of a broader European phenomenon and the result of organic national aspirations of the Croatian people and their Yugoslav inclinations. For instance, the Historical Museum hosted an exhibition in 1969 on the nineteenth-century Revivalist Vatroslav Lisinski. Aside from his work as a writer and teacher, Lisinski was one of the earliest Croatian composers of folk-based compositions essential to nineteenth-century European Romanticism. In composing the first opera in the Croatian language, Lisinski was fundamental to the development of Croatian Yugoslav musical culture, elevating Croat accomplishments to an "unusually important position" within Europe and "affirming the musical culture of Croatia and the other people of our socialist community" (Vatroslav Lisinski 1969, 1). A similar story was told in an exhibition on Antun Dobronić, an early twentieth-century composer who focused on developing a 
unique Croatian musical style based upon folk culture and tradition. Part of a "new generation of Croatian composers" who looked to folk music as "the sole basis for their works," Dobronić was credited for his contributions to a bourgeoning Yugoslav musical culture that reflected his ideological commitment to Yugoslavism (Antun Dobronić 1979, 1-3).

This link was spelled out more explicitly in a 1971 exhibition, "125 Years of Croatian Opera," which juxtaposed the South Slavic character of Zagreb's theater with repeated Germanization and Magyarization efforts by the Habsburg authorities. For instance, the 1843 premier of the first Croatian opera by Vatroslav Lisinski, in collaboration with "extraordinary talents" such as Sodonija Rubido-Erdoby ("the first Illyrian Prima Dona") and Ogjan Štriga ("the Illyrian Bard"), was met with "enormous enthusiasm." Shortly afterward, however, the theater was closed by an "Austrian absolutist regime pursuing violent Germanization" that thwarted "all the positive developments to create a national theater" (Batušić 1971, 1). Similarly, the achievements of the next three decades, such as the formation of an all-Yugoslav ensemble touring throughout Europe and the United States, were followed by another closure of the theater by the new Hungarian Ban, Károly Khuen-Héderváry (2). Nonetheless, by the turn of the century the theater was hosting European operas and concerts, as well as incorporating new productions by South Slavic composers that cemented Croatia and the South Slavs within the broader European cultural currents (7).

Along with framing these cultural developments within a common European trajectory, the Historical Museum emphasized common South Slav heritage, particularly in reference to Serbian and Montenegrin cultural treasures. While this was certainly colored by the need to repair the Croat-Serb cleavages of the 1930s and 1940s through the socialist Yugoslav concept of "brotherhood and unity," producing the myth of common South Slav culture was also an integral part of the "authentic and mediatory" essence of Yugoslavism previously mentioned. Take for instance a 1970 exhibition on the Montenegrin Bay of Kotor in collaboration with the Kotor Maritime Museum. Framing the bay as "one of our most important maritime centers" throughout the medieval and early modern periods, the exhibition highlighted Kotor's South Slavic character while almost entirely leaving out its substantial Venetian influences. For instance, the exhibition told us the bay became a maritime power as an Illyrian province under the Romans and this tradition was continued in the ninth century by "Slavic immigrants" who founded their own navy and turned Kotor into a major center of European trade between the Balkan Peninsula and the Adriatic Sea (Pomorstvo Boke 1970, 1). Likewise, the bay contributed to the larger South Slavic legacy by producing significant figures such as Ivan Visin, "the first Yugoslav to circumnavigate the world" (3). Finally, the exhibition highlighted two twentieth-century events that expressed the bay's distinct Yugoslav character and "tradition of freedom:" a sailor revolt against the Austro-Hungarian Empire in 1918 inspired by the October Revolution and a 1941 maritime battle against Italian forces wherein members of the warship "Zagreb" sunk their own ship in order to prevent it from falling into hands of Italian fascists (3).

The Historical Museum also held exhibitions on the Serbian Orthodox tradition within Croatia, going as far as to establish a separate department within the museum, The Museum of the Serbs in Croatia. The department's collections consisted of Serbian cultural and religious items protected by local Orthodox authorities during the Ustaša regime and came into being on the initiatives of the Committee of Serbs in Croatia and the Serbian cultural society Prosvjet in 1946. At an ideological level, this department was clearly linked to the larger myth of socialist Yugoslavism with the intent to downplay the wartime conflicts between ethnic Croats and Serbs while elevating the long history of mutual respect and interests in the territory of Croatia. A 1948 article in the Zagreb-based journal Historical Anthology 
spells out this ideological orientation quite clearly. Describing the department as a "lasting monument to the love, brotherhood, and unity of the Serbian and Croatian people," the article claims that the department was rooted in the historically shared "interest of the Serbian and Croatian national masses in the struggle against foreign conquerors and class oppressors" (Moačanin 1948, 218-221).

Throughout the socialist period, the holdings of this department provided the basis for various exhibitions on the history of Serbs in Croatia. These exhibitions recognized the broader Eastern Slavic influences side by side with native Serbian innovations and accomplishments as a way of cementing the multinational and multiconfessional character of the territory of Croatia. An exhibition on the Orahovica monastery in eastern Croatia, for example, described the exterior architecture as Moravian in character, while the interior paintings were of a distinctly Serbian medieval tradition, a sort of fusion of the two. Furthermore, the monastery was a center of Slavic learning that held Russian and Ukrainian writings on philosophy, history, literature, science, agriculture, and physics, as well a site for the development of Serbian metallurgy "characteristic of the goldsmiths of the Balkans during the 17th century" (Starine Manastira Orahovice 1976). Likewise, a 1972 exhibition on the Iconostasis painting school of Gomirje monastery told a similar story, wherein Russian and Ukrainian Orthodox iconostasis painting traditions served as the foundation for the development of a Serbian school of painting unique to itself. Recognized as a significant cultural monument, this monastery was restored by the Yugoslav Academy of Arts and Sciences, revealing Gomirje's "true face, clumsy, lovable and naïve, until now hidden by grime, smear and wormholes" (Borčić 1972, 3). Therefore, by cementing the cultural history of Serbs in Croatia as part of a broader Eastern Slavic cultural sphere, the Historical Museum reinforced the cultural "in-between-ness" of socialist Yugoslavia that served to bind its various peoples and multiple religious confessions.

In constructing the mythology of socialist Yugoslavism in Croatia, the Historical Museum could draw on a much longer and deeper history than the Revolutionary Museum. Selectively appropriating older national figures who in one way or another represented the socialist Yugoslav ideal, the Historical Museum reified the historical continuity of the Communist regime and the Croatian people's drive toward Yugoslavism. Similarly, the Historical Museum played an important role in cementing notions of Yugoslav culture as it exhibited and narrated material evidence of its national particularisms, its pan-Yugoslav elements, and its general European heritage, all while lauding the Communist state as protector of each nation's cultural legacy. In doing so, the Historical Museum of Croatia simultaneously functioned as a national and supranational institution that carefully walked the line of nationalist historiography by amalgamating its traditional focus on cultural heroes, national awakenings, and popular uprisings with stories of Croatia's multinational, multiconfessional, and proto-socialist past.

\section{Conclusion: continuities and alterations in the post-socialist period}

On 31 May 1991, the Museum of the Revolution of the Croatian People and the Historical Museum of Croatia were merged under the guidance of the Culture Ministry and renamed the Croatian History Museum. The Revolutionary Museum was decommissioned as an independent institution, most of its staff were fired, and its collections were transferred to the Croatian History Museum. For the most part, the collections of the Revolutionary Museum have been employed only sparingly by the History Museum, which suggests a contemporary discomfort with the recent socialist past and a general rejection of socialist Yugoslav heritage in the story of the Croatian nation (Čaldarović 2008, 109). At the 
symbolic level at least, this closure cemented the end of socialist Yugoslav museology in Croatia and ushered in the return of ethno-national museology in the modern context of post-socialist Eastern Europe.

Having developed an ethno-national-based museology and mythology characteristic of many national museums in Europe and worldwide, it would seem that the Croatian History Museum has crossed the threshold from an institution of a Communist state to an institution of a liberal-democratic state. To leave it at this, though, would be misleading, for the History Museum in many ways has continued to exhibit and narrate the history of the Croatian nation with similar mythological tropes and along similar museological principles as during the socialist Yugoslav period. In both a literal and discursive sense, the Revolutionary Museum and the Historical Museum effectively contributed to the "raw material" for Croatian nation-building in the post-1991 context, providing not only national frameworks to be appropriated and altered, but also the practical foundation of contemporary Croatian museology. Thus, it is not surprising to see a good degree of continuity between the exhibition practices of both museums during the socialist Yugoslav state and the practices of the History Museum in the post-1991 period.

One example is the many exhibitions on the 1990s' civil war, for which the Croatian History Museum has adopted rhetoric and tropes employed by the Revolutionary Museum, such as popular heroism, anti-fascism, and national liberation, only now oriented toward Croatia as a democratic nation-state. Some examples include: "How Croatia Defended Itself: Small Arms in the Homeland War '91," a 1994 exhibition highlighting the role of poorly armed, popular militias in defending the nation against Serb aggression; "Lipik and Pakrac in the Homeland War," a traveling 1994 exhibition documenting the wartime atrocities committed by the "foreign aggressors," Serbs, in the hot spring resort towns of Lipik and Pakrac; "Zadar Monuments," a 1996 exhibition on the destruction of Zadar in both World War II and the 1990s' war; and, finally, "The Homeland War," a 2012 exhibition that employed an unapologetic, nationalist, and anti-Serbian discourse (Ivanuš 1996; Ivanuš and Fabijanec 1994; Jelačić 1994; Rešetar, Nevešćanin, and Smetko 2013). Likewise, the Croatian History Museum has occasionally appropriated objects from the Revolutionary Museum and exhibited them as material proof of Croatia's anti-fascist tradition and liberal-democratic values while exorcising them of their previous socialist Yugoslav implications. These examples include: "Croatian Political Posters, 1940-1950," a 1991 exhibition of World War II-era political posters related to Croatia's liberation and drive toward democracy; "Art of the Croatian Anti-Fascist Resistance," a 1994 exhibition that used the same material as the previously discussed "Art in the National Liberation Struggle of Croatia," only now purged of its socialist meaning; and "Ivan Goran Kovačić and His Work," a 2003 exhibition on the Croat poet turned Partisan now framed as a distinctly Croat national hero and martyr murdered by Serbian Chetnik forces (Benyowsky 2003; Ivanuš 1994; Pavičić 1991).

Likewise, the Croatian History Museum has continued to mythologize the historical precedents of the current state, only now reworked to fit its new ethno-national, liberaldemocratic nature. For instance, it has held exhibitions on the political tradition of liberal democracy in Croatia, various popular movements or uprisings for national liberation, and the myth of state right under the Hungarian Crown. Not surprisingly, these exhibitions have emphasized ethno-national elements at the expense of the South Slavic context: "Stjepan Radić," a 1991 exhibition on the key interwar politician and leader of the Croatian Peasant Party who ardently fought for Croatian autonomy within the Kingdom of Yugoslavia; “The People's Movement of 1883 and 1903," a 1993 exhibition on two failed peasant revolts, now framed as national movements; "Symbols of Power and Honor in Croatia in 
the 19th Century," a 1994 exhibition displaying the material remains of those governors, aristocrats, and bureaucrats who fought for Croatian national independence during the nineteenth century; and "Reminiscences of One Ban," a 2009 exhibition on Ban Jelačić, the governor of Croatia between 1848 and 1859 who is credited with establishing the foundation for modern Croatian civil society (Borošak-Marijanović 1994; Jurdana 1991, 1993; Smetko 2009). Similarly, the Croatian History Museum held the following two exhibitions dedicated to the concept of state right during the Hungarian and later Habsburg period: "All Hail the Sabor," a 1997 exhibition tracing the Croatian parliamentary tradition during Habsburg rule and moments of national assertion within it; and "Koloman's Way," a 2002 exhibition on the eleventh-century king of Hungary, Coloman, who first established the dual crown between Hungary and Croatia (Jurdana, Beusan, and Ančić 2002; Slava Sabora 1997).

While these exhibitions speak to the survival of the basic mythological frameworks developed under socialism and their influence on current conceptions of the Croat nation, they also represent the death of the Yugoslav idea in mainstream Croatian history. Many of the mythological tropes and frameworks have indeed survived in altered forms but within the Croatian History Museum, the history of the nation has been effectively cleansed of its South Slavic heritage, specifically of its Serbian or Yugoslav elements, and placed within its own particular national frameworks. In this sense, the Croatian History Museum has returned to its original, ethno-national role of "anchoring" the nation in the material evidence and scientific discourse it presents, lending it weight and resilience, and identifying "the distinctive qualities of national identity" (Knell 2011).

It is difficult to measure with any certainty the direct influence of the Croat-Yugoslav experiment on contemporary understandings of the nation, and at any rate it is beyond the scope of this study. At the specific institutional level, however, there is a good degree of conceptual continuity in the Croatian History Museum, which is perhaps representative of larger ideological or cultural continuity within modern Croatian society. Precisely because these museological myths have survived, the Communist period must be better understood as a period of negotiation between specifically national claims and a supranational, socialist framework that continues to shape contemporary understandings of the Croatian nation. This is especially true in the case of the former Yugoslavia but likely applies to many of the former Communist states.

Unfortunately, there is surprisingly little literature on Communist museology, as most scholarly works treat the Communist past merely as a negative point of comparison with the post-socialist experience and fail to study how and what these museums were actually doing during the Communist period. Even more, this literature often focuses on the early Communist, namely Stalinist, experience and therefore tells us little about how native Communist parties in the post-Stalinist decades conceptualized nationhood within a Communist ideology that was fundamentally internationalist and supranational (Dovydaityte 2010; Kaluza 2011; Khazanov 2000; Konski 2010; Runnel, Tatsi, and Pruulmann-Vengerfeldt 2011; Sharenkova 2011). Part of the reason for this is a reluctance within many post-socialist societies to recognize the Communist period as part of their national heritage. At the level of popular politics, it is most common to either ignore or demonize the Communist past as nothing more than an external, unnatural, and imposed ideological order, devoid of indigenous participation, intrinsically anti-national, and therefore outside the realm of national heritage. Thus, when national museums engage with the Communist past, it is often used merely as a negative space against which contemporary society and the nation are defined in idealized terms (Badica 2011; Berdahl 2008; James 2005). 
In the case of Croatia, the Communist past is generally avoided or written out of the story, which is indicative of a general discomfort with the recent past (Pavlaković, forthcoming). Indeed, it seems the 1990s' "Homeland War" is the only major event in recent history considered politically safe enough for the state to engage with. Not surprisingly, then, the Croatian History Museum since 1991 has extensively exhibited the 1990s' war alongside older national heroes and triumphs while effectively writing the Communist past out of Croatian national history and heritage. Despite this, the legacy of the socialist Yugoslav experiment is very much alive within the Croatian History Museum. The museum has continued to exhibit and narrate Croatian national history along the same, if inverted, mythological paradigms developed during the socialist period. Croatian history is still the history of a nation shaped by wartime heroism and popular resistance, as well as its historical drive toward national assertion and its current political state. Even if now distinctly non-Yugoslav, the national mythology of the Croatian History Museum is nonetheless reminiscent in both museological form and material content of the ideology of socialist Yugoslavism developed in the preceding decades.

\section{Notes}

1. It bears mentioning that throughout the ebb and flow of Yugoslav politics, there were occasions when this official culture was challenged or subverted through official cultural organs. Yugoslav rock music, for instance, was an outgrowth of state-supported folk music that by the late 1970s had produced groups such as Bijelo Dugme and Zabranjeno Pušenje, who on multiple occasions rebelled against official Communist culture with songs like "Spit and Sign, My Yugoslavia," and "How Beautiful It Is to be Stupid" (Ramet 2002). As I will show throughout this paper, however, these two museums remained remarkably loyal to the official party line, even at the height of events such as the Croatian Spring. This alone tells us a great deal about the nature of these institutions and how deeply embedded they were in the larger nexus of official state culture.

2. I borrow the term from Cristea and Radu-Bucurenci's work on Romanian museums in the postsocialist period. Traditional national museums have often functioned as so-called "Temples of Truth" for the civic religion of nationalism that provide a space for worship and reverence of the sacred nation. "The visitor enters like a Temple, to receive a single Truth, Reality, uniqueness, and accumulation of information for the better identification with an ideal." Therefore, in a Temple of Truth, there exists only a singular narrative that the museum space guides the visitor toward; nowhere is there a space for critical engagement with the objects, for any sort of plurality of voices, any questions posed, or any alternative narratives (Cristea and Radu-Bucurenci 2008, 277).

3. Integrating Croatia's popular heroism into the Yugoslav Partisan narrative bears particular significance. According to Stevo Đurašković, in the late 1950s, some military historians of primarily Serb and Montenegrin descent argued that the National Liberation Struggle (NOB) consisted primarily of ethnic Serb and Montenegrin forces. Likewise, these historians claimed that most of the ethnic Slovenes and Croats joined only toward the end of the war and in much smaller numbers, while the Croats in particular were "resistant to the very idea of Yugoslavia as a polity" (Đurašković 2014, 62). By the 1960s, however, some Croatian historians, including Franjo Tuđman, began to challenge this narrative by "Croatizing" the NOB while rejecting the absolute guilt of Croats for the Ustaša and Jasenovac. Ultimately, Tuđman's more extreme nationalist interpretation was rejected and he was expelled from the party in 1967. Yet, under the guidance of Vladimir Bakarić and his cultural policy of legitimizing the Croatian Communist movement, the narrative of Croatia's wartime experience began to include more ethnic Croats in the revolutionary events of 19411945 (64).

\section{References}

Secondary

Aronsson, Peter. 2011. "Explaining National Museums: Exploring Comparative Approaches to the Study of National Museums." In National Museums: New Studies from Around the World, edited by Simon J. Knell, Peter Aronsson, and Arne Bugge, 29-54. London: Routledge. 
Badica, Simina. 2011. "Same Exhibitions, Different Label? Romanian National Museums and the Fall of Communism." In National Museums: New Studies from Around the World, edited by Simon J. Knell, Peter Aronsson, and Arne Bugge, 272-289. London: Routledge.

Banac, Ivo. 1984. The National Question in Yugoslavia: Origins, History, Politics. Ithaca, NY: Cornell University Press.

Berdahl, Daphne. 2008. "Re-Presenting the Socialist Modern: Museums and Memory in the Former GDR.” In Socialist Modern: East German Everyday Culture and Politics, edited by Katherine Pence and Paul Betts, 345-366. Ann Arbor: University of Michigan Press.

Bryant, Chad Carl. 2007. Prague in Black: Nazi Rule and Czech Nationalism. Cambridge, MA: Harvard University Press.

Čaldarović, Dubravka Peić. 2008. "History Museums in a Changing Political Environment." In Museums and Universal Heritage: History in the Area of Conflict between Interpretation and Manipulation, Marie-Paule Jungblut, 100-106. Luxembourg: ICMAH.

Case, Holly. 2009. Between States: the Transylvanian Question and the European Idea during World War II. Stanford, CA: Stanford University Press.

Cristea, Gabriela, and Simina Radu-Bucurenci. 2008. "Raising the Cross: Exorcising Romania's Communist Past in Museums, Memorials and Monuments." In Past for the Eyes: East European Representations of Communism in Cinema and Museums After 1989, edited by Oksana Sarkisova and Péter Apor, 275-305. Budapest: Central European University Press.

Djilas, Aleksa. 1991. The Contested Country: Yugoslav Unity and Communist Revolution, 19191953. Cambridge, MA: Harvard University Press.

Djokić, Dejan. 2003. Yugoslavism: Histories of a Failed Idea, 1918-1992. London: Hurst.

Dovydaityte, Linara. 2010. "Which Communism to Bring to the Museum? A Case of Memory Politics in Lithuania." In Istorijos (Re)konstrukcijos Nuo 1945-uju iki Dabar [Performing History from 1945 to the Present], edited by Linara Dovydaitytè, Edgaras Klivis, Rūta Mažeikienè, and Jurgita Staniškytė, 80-87. Kaunas: Vytautas Magnus University.

Đurašković, Stevo. 2014. "Nation-building in Franjo Tuđman's Political Writings." Politicka Misao: Croatian Political Science Review 51 (5): 58-79.

Fichter, Madigan. 2016. "Yugoslav Protest: Student Rebellion in Belgrade, Zagreb, and Sarajevo in 1968." Slavic Review 75 (1): 99-121.

James, Beverly A. 2005. Imagining Postcommunism: Visual Narratives of Hungary's 1956 Revolution. College Station: Texas A \& M University Press.

Judson, Pieter M. 2006. Guardians of the Nation: Activists on the Language Frontiers of Imperial Austria. Cambridge, MA: Harvard University Press.

Kaluza, Karoline. 2011. "Reimagining the Nation in Museums: Poland's Old and New National Museums." In National Museums: New Studies from Around the World, edited by Simon J. Knell, Peter Aronsson, and Arne Bugge, 151-162. London: Routledge.

Khazanov, Anatoly M. 2000. "Selecting the Past: The Politics of Memory in Moscow's History Museums." City and Society 12 (2): 35-62.

King, Jeremy. 2002. Budweisers into Czechs and Germans: A Local History of Bohemian Politics, 1848-1948. Princeton, NJ: Princeton University Press.

Knell, Simon J. 2011. "National Museums and the National Imagination." In National Museums: New Studies from Around the World, edited by Simon J. Knell, Peter Aronsson, and Arne Bugge, 328. London: Routledge.

Konski, Karin. 2010. "Sovietization and the Estonian National Museum during the 1940s-1950s." Journal of Ethnology and Folkloristics 1 (1): 29-38.

Lampe, John R. 2000. Yugoslavia as History: Twice there was a Country. Cambridge: Cambridge University Press.

Molyneaux, Brian. 1994. "Introduction: The Represented Past." In The Presented Past: Heritage, Museums, and Education, edited by Peter G. Stone and Brian Molyneaux, 1-13. London: Routledge.

Orzoff, Andrea. 2009. Battle for the Castle: The Myth of Czechoslovakia in Europe, 1914-1948. New York: Oxford University Press.

Patterson, Patrick Hyder. 2012. Bought \& Sold: Living and Losing the Good Life in Socialist Yugoslavia. Ithaca, NY: Cornell University Press.

Pavlaković, Vjeran. Forthcoming. "(Re)constructing the Past: Museums in Post-Communist Croatia." In PostCommunist Museums, edited by Constantin Iordachi and Peter Apor. Budapest: Central European University Press. 
Perica, Vjekoslav. 2002. Balkan Idols: Religion and Nationalism in Yugoslav States. Oxford: Oxford University Press.

Pintar, Olga Manojlović, and Alkesandar Ignatović. 2011. "National Museums in Serbia: A Story of Intertwined Identities." In Building National Museums in Europe 1750-2010. Conference Proceedings from EuNaMus; European National Museums: Identity Politics, the Uses of the Past and the European Citizen, 779-812. Bologna, April 28-30.

Ramet, Sabrina P. 2002. Balkan Babel: The Disintegration of Yugoslavia from the Death of Tito to the Fall of Milošević. Boulder, CO: Westview Press.

Reill, Dominique Kirchner. 2012. Nationalists Who Feared the Nation: Adriatic Multi-Nationalism in Habsburg Dalmatia, Trieste, and Venice. Stanford, CA: Stanford University Press.

Runnel, Pille, Taavi Tatsi, and Pille Pruulmann-Vengerfeldt. 2011. "Who Authors the Nation? The Debate Surrounding the Building of the New Estonian National Museum." In National Museums: New Studies from Around the World, edited by Simon J. Knell, Peter Aronsson, and Arne Bugge, 325-338. London: Routledge.

Sharenkova, Radostina. 2010. "Forget-me(-not): Visitors and Museum Presentations about Communism Before 1989." History of Communism in Europe 1 (1): 65-82.

Sharenkova, Radostina. 2011. "After the Fall of the Berlin Wall: Nationalism and Multiculturalism at the Bulgarian National Ethnographic Museum." In National Museums: New Studies from Around the World, edited by Simon J. Knell, Peter Aronsson, and Arne Bugge, 418-428. London: Routledge.

Zahra, Tara. 2008. Kidnapped Souls: National Indifference and the Battle for Children in the Bohemian Lands, 1900-1948. Ithaca, NY: Cornell University Press.

\section{Primary}

Antun Dobronić: Skladatelj, 1878-1955. 1979. Zagreb: The Historical Museum of Croatia.

Babić, Katarina. 1973. Hrvatska 1943. Zagreb: Museum of the Revolution of the Peoples of Croatia.

Batušić, Slavko. 1971. 125 Godina Hrvatske Opere: 100 Godina Stalne Opere Hrvatskog Narodnog Kazališta. Zagreb: The Historical Museum of Croatia.

Bauer, Antun. 1953. "Muzejska Propaganda i Povremene Muzejske Izložbe." Muzeologija: Zbornik za Muzejsku Problematiku 2 (1953): 69-100.

Benyowsky, Lucija. 2003. Ivan Goran Kovačić i Njegov Zavičaj. Zagreb: Croatian History Museum.

Borčić, Vera. 1972. Ikonostas Slikarske Škole Simeona Baltića iz Gomirja. Zagreb: The Historical Museum of Croatia.

Borošak-Marijanović, Jelena. 1994. Znamenja Vlasti i Časti u Hrvatskoj u 19. Stoljecu. Zagreb: Croatian History Museum.

Borošak-Marijanović, Jelena, and Ela Srzić. 1980. J.J. Strossmayer. Zagreb: The Historical Museum of Croatia.

Božić, Mirko. 1974. Uvod: Likovna Umjetnost u NOB-I Hrvatske. Zagreb: Museum of the Revolution of the Peoples of Croatia.

Dančević, Luka. 1975. Pučki Ustanak Matija Ivanića i Njegovo Doba. Zagreb: The Historical Museum of Croatia.

Dešković, Ksenija, and Dolores Ivanuša. 1970. Četvrt Stoljeća Našeg Razvitka. Zagreb: Museum of the Revolution of the Peoples of Croatia.

Ivan Kukuljević Sakcinski. 1960. Zagreb: The Historical Museum of Croatia.

Ivanuš, Reah. 1994. Umjetnost Hrvatskog Antifašističkog Otpora. Zagreb: Croatian History Museum. Ivanuš, Reah. 1996. Zadarski Mementi. Zagreb: Croatian History Museum.

Ivanuš, Reah, and Boris Fabijanec. 1994. Lipak i Pakrac u Domovinskom Ratu. Zagreb: Croatian History Museum.

Ivanuša, Dolores. 1988. Partizanska Karikatura. Zagreb: Museum of the Revolution of the Peoples of Croatia.

Jelačić, Ranko. 1994. Čime se Branila Hrvatska: Ručno Vatreno Oružje u Domovinskom Ratu '91. Zagreb: Croatian History Museum.

Jurdana, Ela. 1991. Stjepan Radić. Zagreb: Croatian History Museum.

Jurdana, Ela. 1993. Narodni Pokreti u Hrvatskoj, 1883 i 1903. Zagreb: Croatian History Museum.

Jurdana, Ela, Mario Beusan, and Mladen Ančić. 2002. Kolomanov Put. Zagreb: Croatian History Museum.

Kolar, Sonja. 1984. Rade Končar: Sekretar CK KPH. Zagreb: Museum of the Revolution of the Peoples of Croatia. 
Kolar, Sonja. 1988. Republičke Nagrade i Društvena Priznanja u SRH. Zagreb: Museum of the Revolution of the Peoples of Croatia.

Kulturni Rad u NOB-i. n.d. Zagreb: Museum of the Revolution of the Peoples of Croatia.

Ljudevit Gaj, 1809-1872. 1972. Zagreb: The Historical Museum of Croatia.

Mateljan, Smiljka. 1974. Likovna Umjetnost u NOB-I Hrvatske. Zagreb: Museum of the Revolution of the Peoples of Croatia.

Moačanin, Fedor. 1948. "Muzej Srba u Hrvatskoj." Historijski Zbornik 1 (1): 217-221.

Pavičić, Snježana. 1986. Andrija Maurović: Stari Maček u NOB-i. Zagreb: Museum of the Revolution of the Peoples of Croatia.

Pavičić, Snježana. 1991. Hrvatski Politički Plakat. 1940-1950. Zagreb: Croatian History Museum.

Pomorstvo Boke Kotorske. 1970. Zagreb: The Historical Museum of Croatia.

Purtić, Andro. n.d. Žene hrvatske u revoluciji. Zagreb: Museum of the Revolution of the Peoples of Croatia.

Rešetar, Matea Brstilo, Ivica Nevešćanin, and Andreja Smetko. 2013. Domovinski Rat. Zagreb: Croatian History Museum.

Schneider, Marijana. 1967. Iz Kulturnog i Društvenog Života Ilirskog Preporoda. Zagreb: The Historical Museum of Croatia.

Ščukanec, Dragutin. 1957. Od Partizahnskih Odreda do Jugoslavenske Armije. Zagreb: Museum of the Revolution of the Peoples of Croatia.

Slava Sabora. 1997. Zagreb: Croatian History Museum.

Smetko, Andreja. 2009. Reminiscences of One Ban. Zagreb: Croatian History Museum.

Stančić, Nikša. n.d. Frano Supilo, 1870-1917. Zagreb: The Historical Museum of Croatia.

Starine Manastira Orahovice. 1976. Zagreb: The Historical Museum of Croatia.

Vatroslav Lisinski, 1819-1847. Život i Djelo. 1969. Zagreb: The Historical Museum of Croatia.

Vojnović, Zdenko. 1953. "Naučno-Prosvjetni Zadaci Muzeja." Muzeologija: Zbornik za Muzejsku Problematiku 1 (1953): 19-33. 